\title{
Лікування та профілактика вірусних інфекцій: нові можливості відомих препаратів
}

\author{
О.В. Шарікадзе \\ Національний університет охорони здоров'я імені П.Л. Шупика, Київ, Україна
} «Головний принцип лікування вірусних інфекцій — допомогти організму самому перемогти вірус»

Професор О.О.ББаранов

\section{Вірусні інфекції - виклики сучасності}

Гострі респіраторні вірусні інфекції (ГРВІ) - найпоширеніша група захворювань, яка характеризується переважним ураженням респіраторного тракту і значно розповсюджена в суспільстві незалежно від віку, місця проживання чи соціального статусу. Сьогодні тема ГРВІ та грипу не втрачає своєї актуальності й обговорю$\epsilon$ ться знову і знову. Інфекція SARS-CoV-2, що турбує кожну людину як у нашій країні, так і в усьому світі, - теж належить до ГРВІ.

За даними Всесвітньої організації охорони здоров'я, вірусні інфекції займають 1-ше місце за показником DALYs (Disability-adjusted life years, роки життя, втрачені внаслідок смерті або втрати працездатності). Це третя (а у країнах з низьким економічним статусом перша) причина летального результату після серцевої та судинної патології. Щорічно відмічають 3-5 млн випадків тяжкого перебігу вірусних інфекцій, серед них 250-500 тис. мають летальний результат.

Щодо грипу, за оцінками Центрів з контролю та профілактики захворювань США (Centers for Disease Control and Prevention (DC), у період 2018-2019 рр. виявлено 35,5 млн випадків захворювання, з них 490600 госпіталізацій та 34200 випадків смерті.

Діти більш сприйнятливі до ГРВІ за рахунок фізіологічної нестійкості імунної системи, перебування здебільшого в людних місцях, у великих соціальних колективах (дитячі садки, школи, розважальні центри), схильності торкатися до всього. Таким чином, діти хворіють на ГРВІ до 7-10 разів на рік. Це вважається нормальним з позицій Всесвітньої організації охорони здоров'я, але батькам, дитина яких хворіє щомісячно, це додає певних труднощів.

На сьогодні відомо >200 респіраторних вірусів, головною точкою дотику яких $\epsilon$ респіраторна система. Проблему становлять частий розвиток ускладнень, особливо для пацієнтів групи ризику, та загострення хронічних захворювань. Респіраторні віруси, метавіруси можуть провокувати розвиток алергічної патології, починаючи з дитячого віку. Тому у 2003 р. була створена Всесвітня програма дій з епідеміологічного нагляду та боротьби з грипом (Global Influenza Programme - GIP), основні постулати якої представлені на сайті Всесвітньої організації охорони здоров'я [1].

Респіраторні віруси мають досить поширену етіологічну структуру (рис. 1). Серед цього різноманіття максимальну кількість у структурі становлять риновіруси, коронавіруси, віруси парагрипу, респіраторно-синцитіальний вірус. Грип, незважаю-

Рисунок 1 Етіологічна структура ГРВІ [2]

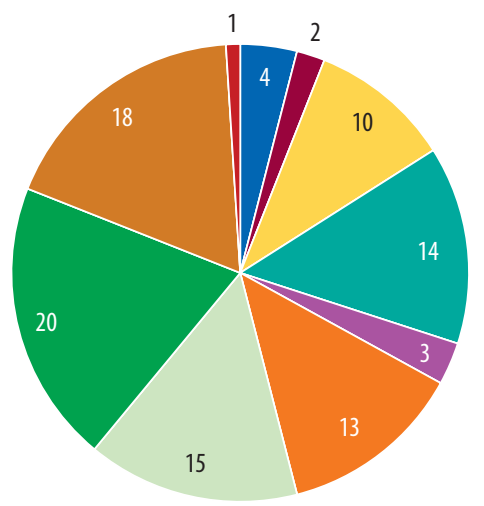

— Бокавіруси
- Аденовіруси
—етапневмовіруси
—арагрип
—рип
— Респіраторно-синцитіальний вірус
Коронавіруси
— Риновіруси
— Збудник не виявлений
— Ентеровіруси (без риновірусів)

чи на те, що $\epsilon$ проблемним захворюванням з високим ступенем інтоксикації, ризиком розвитку ускладнень і летального результату, становить лише 3\%. Ентеровіруси, бокавіруси, аденовіруси становлять близько 1-4\%, тобто незначну частку в загальній структурі вірусних інфекцій.

Неможливо говорити про лікування без розуміння особливостей патогенезу захворювання, тому далі розглянемо основні ланки патогенезу ГРВІ.

\section{Головні ланки патогенезу ГРВІ}

Реплікаційний цикл респіраторних інфекцій, незалежно від типу вірусу, проходить 6 основних фаз циклу:

1. Зараження (через слизові оболонки або шкіру).

2. Адсорбція та проникнення вірусу в клітину хазяїна.

3. Транскрипція вірусної РНК (для ДНК-вмісних вірусів ДНК) та трансляція вірусних білків.

4. Реплікація вірусної РНК (ДНК).

5. Самоскладання віріонів.

6. Наступний вихід їх із клітини.

Результатом таких особливостей патогенезу $\epsilon$ пошкодження життєво важливих органів. Так, оскільки репродукція вірусів може відбуватися в мітохондріях, відмічається зниження синтезу аденозинтрифосфату (АТФ) - головного енергетичного субстрату організму людини. Розвиток віремії призводить до загального токсикозу, «цитокінового шторму» і таких проявів, як гіпертермія, головний біль, загальна слабкість. Результатом приєднання бактеріальної інфекції $є$ розвиток ускладнень (пневмонія, бактеріальний синусит, нефрит тощо).

Вірусні білки значно пригнічують активність імунної системи, і особливе місце в організмі в захисті імунної системи посідають інтерферони - клас низькомолекулярних глікопротеїнів, які чинять не тільки противірусну, але й антибластомну, протипухлинну, певну імуностимулюючу дію. Класів інтерферонів дуже багато i, говорячи про противірусний імунітет, слід зазначити, що основними класами, які захищають від респіраторних вірусів, $\epsilon$ інтерферон-а та інтерферон- $\beta$. Інтерферони відповідають за продукцію лейкоцитів, фібробластів, лімфоцитів під впливом інтерфероногенів. Найбільш вивчена властивість інтерферонів - здатність перешкоджати розмноженню вірусів.

\section{Як же відбувається цей захист?}

Клітина-хазяїн при зараженні вірусом починає продукцію інтерферону, який виходить з клітини і вступає в контакт із сусідніми клітинами, роблячи їх несприйнятливими до вірусу. Інтерферон діє, запускаючи ланцюг подій, що призводять до пригнічення синтезу вірусних білків і в деяких випадках контролюють і запобігають збірці та синтезу вірусних частинок шляхом активації олігоаденілатциклази. Не можна стверджувати, що інтерферон чинить пряму противірусну дію, але він викликає такі зміни у клітині, які перешкоджають розмноженню вірусу. Тому варто стимулювати утворення інтерферонів, але воно може стимулювати не тільки інтактні віруси, але й інші різні агенти, наприклад деякі інактивовані віруси, дволанцюжкові молекули РНК, синтетичні дволанцюжкові олігонуклеотиди, бактеріальні ендотоксини та ін. Біологічна активність інтерферону дуже висока: достатньо однієї молекули інтерферону, щоб зробити клітину резистентною до вірусної інфекції. 


\section{Клінічні ознаки ГРВІ}

Головні клінічні ознаки: кашель (небезпечний симптом, який відмічають у близько 50\% хворих, при цьому слід зазначити, що респіраторні віруси здатні викликати хронічний кашель, іноді тривалістю 2-4 тиж і більше); біль у горлі (у майже $40 \%$ хворих); ринорея; закладення носа («нежить»); підвищення температури тіла.

Додаткові: біль у м'язах (майже в половині випадків захворювання); відчуття втомлюваності; головний біль; втрата апетиту (при інфекції SARS-CoV-2 також - втрата нюху).

Сьогодні, говорячи про клінічну картину ГРВІ, варто відокремити COVID-19 з огляду на високу стурбованість щодо цього захворювання, симптоми якого варіюють від легкого до тяжкого ступеня. Але іноді забуваємо про проблему інших респіраторних вірусних інфекцій - грипу, парагрипу, які можуть викликати такі захворювання, як тяжкий стенозуючий ларингіт, ларинготрахеїт. Тому табл. 1 дає змогу принаймні частково провести диференційну діагностику симптомів COVID-19, грипу та інших проявів ГPВІ.

Таблиця 1 Симптоми COVID-19, грипу та застуди

\begin{tabular}{lccc}
\hline \multicolumn{1}{c}{ Симптоми } & $\begin{array}{c}\text { CоVID-19 } \\
\text { (симптоми } \\
\text { варіюють } \\
\text { від легкого } \\
\text { до тяжкого } \\
\text { ступеня) }\end{array}$ & $\begin{array}{c}\text { Грип (швидке } \\
\text { виникнення } \\
\text { симптомів) }\end{array}$ & $\begin{array}{c}\text { Застуда } \\
\text { (поступове } \\
\text { виникнення } \\
\text { симптомів) }\end{array}$ \\
\hline Біль від легкого до сильного & Іноді & Часто & Іноді \\
\hline Кашель & Часто & Часто & Часто \\
\hline Діарея & Іноді удітей & Часто, особливо & Ні \\
\hline Втома & Інодей & Часто & Іноді \\
\hline Лихоманка або озноб & Поширені & Поширені & Рідко \\
\hline Головний біль & Іноді & Поширений & Рідко \\
\hline Втрата смаку або нюху & Поширені, раптові & Рідко & Іноді \\
\hline Нудота або блювання & Іноді & Іноді & Ні \\
\hline Нежить або закладений ніс & Рідко & Іноді & Часто \\
\hline Задишка & Іноді & Ні & Ні \\
\hline Чхання & Немає & Іноді & Поширене \\
\hline Біль у горлі & Іноді & Іноді & Часто \\
\hline
\end{tabular}

Біль від легкого до сильного, міалгія, загальна слабкість при початку інфекції COVID-19 нечасто турбують пацієнта, і швидше за все - це артралгія. А ось для грипу характерними $\epsilon$ міалгія, виражені симптоми інтоксикації. Для застуди це взагалі нехарактерно.

Кашель може виникати при будь-якому типі респіраторної вірусної інфекції, і тому потребує проведення диференційного діагнозу.

Діарея - симптом, який представляє інтерес, оскільки перші симптоми COVID-19 можуть виникати з боку шлунково-кишкового тракту, і SARS-CoV-2 вражає слизову оболонку кишечнику, тому діарея характерна для респіраторних інфекцій, але частіше цей симптом відмічають у дітей. Грип теж може викликати діарею, особливо в дитячому віці, але це швидше реакція на виражену інтоксикацію.

Втома, лихоманка та озноб характерні для COVID-19 та грипу, але виражена лихоманка нехарактерна для респіраторних вірусних інфекцій. Симптоми інтоксикації у вигляді головного болю для COVID-19 інтенсивні, але не так часто, тоді як для грипу вони поширені та дуже рідко виникають при застуді.

Втрата нюху або смаку - патогномонічна ознака COVID-19. Ці симптоми поширені, виникають раптово. Відсутність відчуття смаку і нюху при закладеності носа при респіраторній інфекції, що відбувається вкрай рідко, вкрай відрізняється від абсолютної відсутності відчуття навіть мінімальних запахів при COVID-19. Деякі пацієнти навіть скаржаться на запахи, які нехарактерні для певного продукту.

Нудота та блювання, притаманні COVID-19, іноді відмічаються при грипі та застуді.
Нежить та закладеність носа нехарактерні для COVID-19, особливо перших його проявів, а притаманні респіраторним інфекціям.

Задишка - це вже ознака ускладнень, тяжкого перебігу і більш характерна для COVID-19. А ось чхання та біль у горлі частіше відмічаються при звичайній застуді.

\section{Лікування}

Існує думка, що вірусну інфекцію можна не лікувати, або навпаки - деякі лікарі вважають, що потрібно активно лікувати з початку перших проявів інфекції. Але першим завданням лікування $\epsilon$ зниження активності вірусів в організмі людини.

\section{Які для цього є інструменти?}

Симптоматичне лікування: зниження температури тіла, знеболення, зменшення вираженості неприємних відчуттів. У країнах Європи вважається, що дитина не повинна страждати від болю, тому що це подовжує тривалість симптомів й самого захворювання, ускладнює процес одужання. Тому якщо дитина скаржиться на головний біль, біль у горлі або наявна лихоманка, яка потребує контролю, - безумовно, слід призначити симптоматичне лікування. Мається на увазі застосування абсолютно різних засобів, але слід зазначити, що вони повинні бути безпечними для пацієнта. Тобто це не мають бути препарати, які можуть викликати побічні симптоми, які потім будуть ускладнювати лікування.

Щодо доцільності призначення антибіотиків - на жаль, це $\epsilon$ проблемою № 1 сімейних лікарів, педіатрів, лікарів інших спеціальностей, які можуть давати рекомендації застосовувати антибіотики при вірусній інфекції, що $\epsilon$ абсолютно неефективним і більше того - небезпечним щодо розвитку ускладнень, якщо антибіотики призначаються без певних показань.

Слід наголосити, що нетрадиційне лікування також може спричинити виникнення побічних симптомів і навіть ускладнень.

Стосовно противірусної терапії: в аптечній мережі сьогодні можна придбати велику кількість противірусних препаратів, тому слід розуміти, що хіміотерапевтичні препарати так чи інакше викликають побічні ефекти, що завжди зазначено в інструкції для застосування препарату. Такі хіміотерапевтичні препарати, як уміфеновір, римантадин, озельтамівір, амантадин, занамівір, мають вузький спектр дії та характеризуються формуванням резистентних вірусних штамів. Наприклад сьогодні штами грипу вже нечутливі до римантадину, який раніше був значно поширений при лікуванні грипу. $€$ чутливість до озельтамівіру, занамівіру, але ці препарати мають дуже вузький спектр дії (тільки вірус грипу), а також характерні певні побічні ефекти, такі як лейкопенія.

Препарати інтерферону також поширені в Україні, але при тривалому застосуванні можуть спричинити грипоподібний синдром, транзиторну гіпо- та гіпертензію, набряки, ціаноз, аритмію, свербіж і сухість шкіри, підвищення рівня печінкових ферментів, судомний синдром, порушення церебральних, ниркових функцій.

\section{Виникає питання: чим лікувати ГРВІ?}

Сучасні лікарі все частіше звертаються до нових терапевтичних підходів. Сьогодні існує відносно новий термін - «біорегулююча терапія». Це новий підхід до вирішення проблеми профілактики і лікування грипу та ГРВІ - метод, який базується на стимуляції факторів неспецифічного захисту, синтезу ендогенного інтерферону. Слід нагадати про добре відомий препарат Афлубін $^{\circledR}$, який дуже часто застосовується, але іноді, призначаючи препарат, лікар не завжди пам'ятає всі нюанси його дії на організм.

Афлубін ${ }^{\circledast}$ - препарат для лікування ГРВІ та грипу, який ефективно лікує ці стани. Препарат можна застосовувати як для профілактики, так і для лікування завдяки тому, що він чинить комплексну противірусну дію при будь-якому типі ГРВІ. Афлубін ${ }^{\circledast}$ підвищує системний та місцевий імунітет, стимулює активність власного ендогенного інтерферону, чинить пряму противірусну дію, м'яку жарознижувальну дію, знижує інтенсивність і скорочує тривалість інтоксикаційного і катарально- 
го синдромів i, що дуже важливо, попереджає розвиток таких ускладнень, як бронхіт, пневмонія, синусит та ін. Це відбувається завдяки прямій стимуляції імунної системи за рахунок вироблення інтерферону, підвищення місцевого імунітету верхніх дихальних шляхів, підвищення рівня Т-хелперів і відновлення хелперно-супресорного співвідношення. Препарат також чинить пряму противірусну дію за рахунок пригнічення розмноження вірусів в організмі людини.

Афлубін ${ }^{\circledast}$ належить до індукторів інтерферону, а інтерферон чинить противірусну дію, активує фактори антивірусного захисту - Т-хелпери, систему комплементу, а також підвищує фагоцитарну активність. У табл. 2 показано залежність дози препарату Афлубін ${ }^{\circledR}$ і титрів інтерферону в сироватці крові і культуральній рідині. Таким чином, одноразовий прийом препарату вже в перші 3 год стимулює вироблення ендогенного інтерферону, і цей ефект зберігається протягом 72 год.

Таблиця 2 Афлубін ${ }^{\circledast}$ - індуктор інтерферону [3]

\begin{tabular}{lccccc}
\hline \multirow{2}{*}{ Дози препарату Афлубін } & \multicolumn{3}{c}{$\begin{array}{c}\text { Титри інтерферону в сироватці } \\
\text { крові, 0д./мл }\end{array}$} & $\begin{array}{c}\text { у культу- } \\
\text { ральній } \\
\text { рідині }\end{array}$ \\
\cline { 2 - 5 } & $\mathbf{3}$ год & $\mathbf{2 4 \text { год }}$ & $\mathbf{7 2 ~ г о д ~}$ & 512 \\
\hline $0,1 \%$ & 0,2 мл & 320 & 60 & 36 & 1024 \\
\hline $2 \%$ & 0,2 мл & 640 & 180 & 110 & 1024 \\
\hline Контроль & 0,2 мл & 640 & 180 & 120 & 0 \\
\hline
\end{tabular}

Дослідження щодо ефективності препарату Афлубін ${ }^{\circledast}$ проведені відомими українськими вченими ще у 2001 р. [4]. I досі препарат зберігає свою активну участь на фармацевтичному ринку, що означає, що він $є$ ефективним і має високий ступінь довіри не тільки у пацієнтів, а й у лікарів. Отже, результати дослідження [4] свідчать, що при прийомі препарату під час захворювання значно знижується інтенсивність та скорочується тривалість проявів інтоксикації та катарального синдрому (рис. 2).

Рисунок 2 Доведений вплив препарату Афлубін ${ }^{\oplus}$ на катаральний та інтоксикаційний синдроми [4]
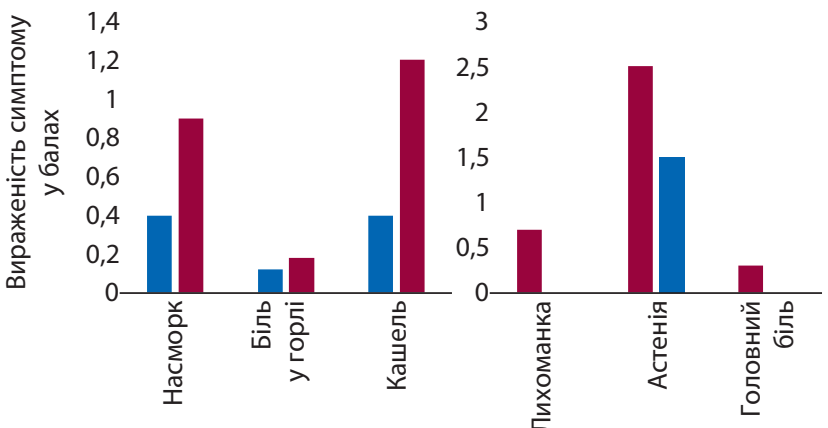

- Афлубін ${ }^{\circledast}+$ симптоматична терапія

- Симптоматична терапія

Ще в одному дослідженні вивчали показник клітинного імунітету дітей після застосування препарату Афлубін ${ }^{\circledR}$ [5]. Доведено, що після застосування препарату достовірно збільшується абсолютна і відносна кількість лімфоцитів і нормалізується субпопуляційне співвідношення CD4/CD8 (рис. 3).

що ж такого $є$ у складі препарату Афлубін ${ }^{\circledR}$, що допомагає активно протидіяти вірусній інфекції в організмі людини?

Афлубін ${ }^{\circledast}$ складається 3 п'яти основних компонентів:

- тирлич (Gentiana), який виявляє протизапальний, антисептичний, жарознижувальний, загальнозміцнювальний ефекти;

- борець (Aconitum), який усуває лихоманку з високою температурою тіла, ознобом і сильним головним болем;

- переступінь білий (Bryonia), що усуває запаморочення, сильний головний біль і біль в очах;

- молочна кислота (Acidum sarcolacticum), яка допомагає при м'язовому болю, блюванні і стані сильної знемоги;
Рисунок 3 Нормалізація показників клітинного імунітету у дітей після застосування препарату Афлубін ${ }^{\circledR}[5]$

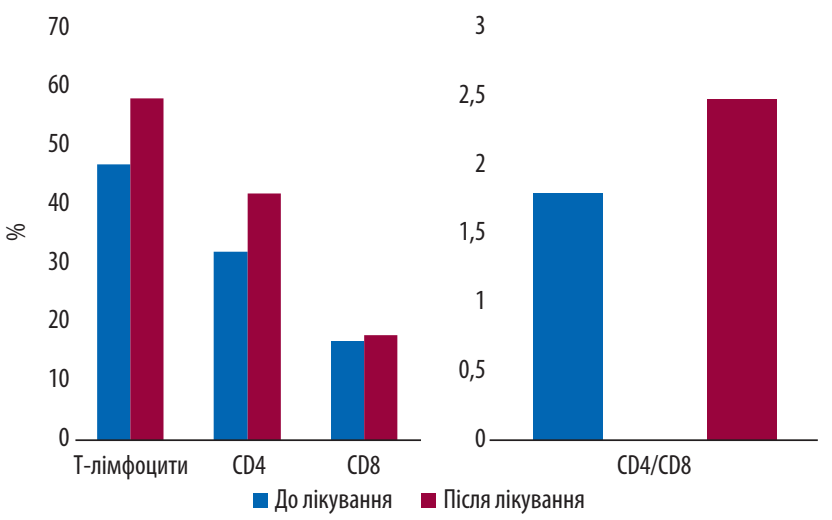

- заліза фосфат (Ferrum phosphoricum), що допомагає усунути симптоми сухого подразливого судомного кашлю, першіння в горлі та біль у грудній клітці.

\section{Як застосовувати Афлубін ${ }^{\circledR}$ і які показання} до його призначення?

Показаннями до застосування препарату Афлубін ${ }^{\circledR} \in$ профілактика та лікування грипу та застуди (ГРВІ). Лікування слід починати практично з перших хвилин після появи симптомів захворювання. Протипоказанням $\epsilon$ виключно підвищена чутливість до будь-якого компонента препарату.

Спосіб застосування та дози препарату Афлубін ${ }^{\circledR}$ представлені в табл. 3 .

Таблиця 3 Спосіб застосування та дози препарату Афлубін ${ }^{\circledR}$

\begin{tabular}{|c|c|c|c|}
\hline \multirow{2}{*}{ Вікова група } & \multicolumn{2}{|c|}{ Разова доза } & \multirow{2}{*}{ Кратність прийому } \\
\hline & Краплі & Таблетки & \\
\hline $\begin{array}{l}\text { Дорослі та діти } \\
\text { віком старше } \\
12 \text { років }\end{array}$ & 10 крапель & 1 таблетка & $\begin{array}{l}\text { 1-2-й день лікування разову дозу } \\
\text { крапель приймати кожні } \\
\text { пів години-годину до поліпшення }\end{array}$ \\
\hline $\begin{array}{l}\text { Діти віком } \\
5-12 \text { років }\end{array}$ & 5-9 крапель & 1⁄2 таблетки & $\begin{array}{l}\text { стану, але не більше } 8 \text { разів на добу, } \\
\text { таблетки — } 3 \text { рази на добу. Далі }\end{array}$ \\
\hline $\begin{array}{l}\text { Діти віком } \\
\text { 2-4 роки }\end{array}$ & 2-4 краплі & & $\begin{array}{l}\text { краплі приимати з рази на добу, } \\
\text { таблетки — } 2 \text { рази на добу } \\
\text { до одужання. } \\
\text { Профілактика: краплі або таблетки } \\
\text { приймати } 2 \text { рази на добу. Тривалість } \\
\text { курсу планової профілактики —- } \\
3 \text { тижні, екстреної — } 3 \text { дні }\end{array}$ \\
\hline
\end{tabular}

\section{Профілактика хвороби - найрозумніше лікування}

Лікувати інфекцію складніше, ніж попередити їі. Тому основними можливостями профілактики ГРВІ $є$ протиепідемічні заходи (такі як миття рук, носіння масок), вакцинація, нутритивна підтримка та імуномодулююча терапія. Стосовно вакцинації вона дійсно ефективна проти грипу, COVID-19, але створення вакцини, яка буде ефективною щодо широкого кола інфекцій дихальних шляхів найближчим часом $є$ дуже малоймовірним. До того ж залишається певна категорія пацієнтів, яким неможливо провести вакцинацію. Нутритивна підтримка, зокрема використання мікронутрієнтів, вітамінів, препаратів заліза, також $\epsilon$ важливою.

Афлубін ${ }^{\circledast}$ для планової профілактики слід застосовувати за 1 міс до сезонного підвищення захворюваності або під час поширення епідемії. Його також можна застосовувати у якості екстреної профілактики для попередження застудного захворювання після контакту з хворим на грип або ГРВІ або після дії провокативних чинників (переохолодження, різка зміна клімату тощо).

У проведених дослідженнях при профілактичному застосуванні препарату Афлубін ${ }^{\circledR}$ захворюваність дітей на грип та ГРВІ становила лише 2,3\%, а без застосування - 34,2\%. Для дорос- 
лих ці показники становили 11,4 та 35,6\% відповідно (рис. 4) [5]. Трохи нижчий показник ефективності профілактичного застосування препарату у дорослих пов'язаний насамперед із наявністю додаткових ризиків.

Рисунок 4 Вплив профілактики препаратом Афлубін ${ }^{\circledR}$ на захворюваність на грип та ГРВІ

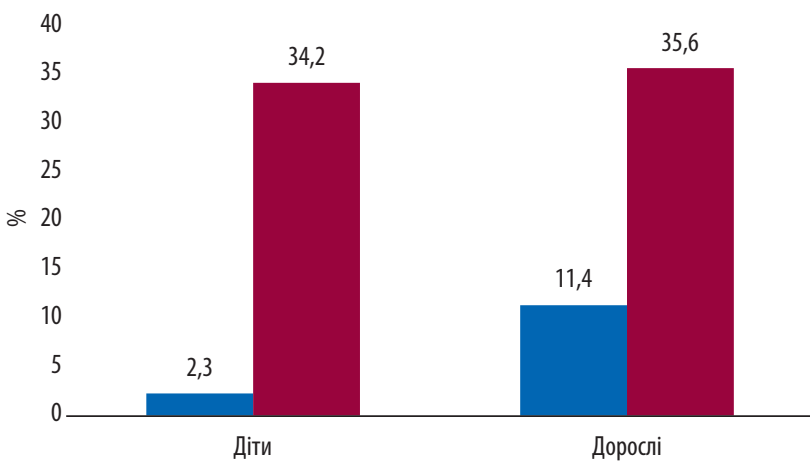

— з застосуванням препарату Афлубін ${ }^{\circledast} \quad$ Без застосування препарату Афлубін

Таким чином, Афлубін ${ }^{\circledast}$ — противірусний препарат для профілактики та лікування грипу та ГРВІ, який:

- підвищує системний і місцевий імунітет;

- чинить пряму противірусну дію;

- скорочує тривалість і зменшує вираженість симптомів;

- попереджає розвиток ускладнень (бронхіт, пневмонія тощо).

Слід зазначити, що в лінійці цього бренду, який добре себе зарекомендував, з'явилася новинка - Афлубін ${ }^{\oplus}$ ІмуФаст, який забезпечує потрійну підтримку організму:

\section{1. Зміцнює імунну систему:}

- ехінацея, бузина, імбир сприяють правильному функціонуванню імунітету;

- вітаміни C, D, B , $_{12^{\prime}}$ фолієва кислота, цинк і селен підвищують опірність організму.

2. Допомагає підтримувати енергетичний рівень:

- вітаміни С, B, B $_{3^{\prime}} \mathrm{B}_{6^{\prime}}, \mathrm{B}_{12^{\prime}}$ фолієва кислота сприяють зниженню стомлюваності, забезпечують енергетичну підтримку організму;

- вітамін С стимулює імунну систему.

3. Пом'якшує подразнення горла, заспокоює кашель:

- бузина пом'якшує прояви застуди/ГРВІ, допомагає заспокоїти подразнення в горлі, кашель і захриплість;

- ментол чинить пом'якшувальний ефект на горло, глотку і голосові зв'язки.

Говорячи про окремі компоненти препарату, слід зазначити, що їхня користь не викликає жодних сумнівів.

Зокрема ехінацея має такі важливі властивості, як стимуляція Т-системи імунітету, підсилення бактерицидної активності клітин. За рахунок пригнічення активності гіалуронідази виявляється значний противірусний ефект. Ехінацея відома як стимулятор центральної нервової системи, використовується у пацієнтів із розладами вегетативної нервової системи, може використовуватися навіть як антидепресант, а також зумовлює суттєву детоксикаційну дію за рахунок можливості виведення радіонуклеотидів і важких металів. Коріння ехінацеї містить глікозиди (ехінокозид), бетаїн, органічні кислоти, ефірну олію, мінеральні речовини (K, Mg, $\mathrm{Fe}, \mathrm{Al}, \mathrm{Se})$ та вітаміни.
Ягоди бузини мають досить насичений склад, містять білок, жири, вуглеводи, клітковину, залізо, магній, вітамін А, але в найбільшій кількості - калій, кальцій та вітамін С (406; 55 та 52 г у 1 гроні ягід бузини відповідно). Користь бузини добре відома ще з народної медицини. Вона чинить місцеву протизапальну дію на слизову оболонку дихальних шляхів, пом'якшує симптоми застуди, має протинабрякові та антиоксидантні властивості.

Імбир чинить знеболювальну та протизапальну дію (завдяки чому його використовують для лікування артриту, головного болю), виявляє виражений зігріваючий ефект, стимулює кровообіг. У дослідженнях екстракт імбиру використовували для контролю і пригнічення активації риновірусів і збудників кишкових інфекцій. Корисною додатковою властивістю імбиру, принаймні за наявності діареї, симптомів кишкових розладів, $\epsilon$ зменшення газоутворення.

Щодо вітамінів у складі препарату, нагадаємо, що вітамін С (аскорбінова кислота) підвищує опірність організму до застудних захворювань, чинить високу антиоксидантну дію, захищаючи клітини від вільних радикалів. Вітаміни групи В сприяють зниженню втоми та відчуття апатії, необхідні для нормального виділення енергії у процесі обміну речовин, сприяють зміцненню імунітету. Вітамін $D_{3}$ бере участь у регуляції імунних реакцій, активує роботу імунітету, зокрема Т-клітин.

Цинк діє як антиоксидант і може стабілізувати мембрани клітин, має вирішальне значення для нормального розвитку та функціонування клітин неспецифічного імунітету. Селен впливає на клітинний імунітет і стійкість до вірусних інфекцій, чинить антиоксидантну дію.

Афлубін ${ }^{\circledast}$ ІмуФаст рекомендований дітям віком старше 7 років і дорослим. 2 льодяники забезпечують добову дозу всіх необхідних вищезазначених речовин. Важливою інформацією для людей, які дотримуються здорового способу життя та здорового харчування, а також осіб із цукровим діабетом, лактазною непереносимістю, непереносимістю глютену, $\epsilon$ те, що Афлубін ${ }^{\circledast}$ ІмуФаст не містить цукру, глютену, лактози, консервантів, штучних барвників, ароматизаторів, желатину і підходить для вегетаріанців.

Перевагами імуностимулятора Афлубін ${ }^{\oplus}$ ІмуФаст є:
- універсальність - за рахунок потрійної підтримки організ-
му (імунітет - енергія - горло);
- потужна формула (вміст діючих речовин у 2 льодяниках
становить 100\% добової норми споживання);
- натуральність компонентів - можна безбоязно поєднува-
ти з іншими препаратами і засобами;
- приємний смак, який перетворює лікування з нудного про-
цесу на задоволення.

\section{Список використаної літератури}

1. www.who.int/teams/global-influenza-programme

2. Купченко А.Н., Понежева Ж.Б. (2016) Современные принципы диагностики и лечения OРВИ. www.medarhive.ru/jour/article/view/483?locale=ru_RU.

3. Волянський Ю.Л. Про противірусна ефективність та токсичні ефекти препарату Афлубін. Харківський НДІ мікробіології та вірусології НАМН України імені ІІІ. Мечникова.

4. КрамарєВ С.0. (2001) Афлубін в комплексній терапії ГРВІ у дітей. Журн. практ. лікаря, 4:60-64.

5. Шостакович-Корецька Л.Р. (1998) Досвід клінічного застосування препарату Афлубін для профілактики і лікування грипу та ГРВІ. Актуальні проблеми медицини, 3.

\section{Відомості про автора:}

Шарікадзе Олена Вікторівна - доктор медичних наук, доцент кафедри педіатрії № 1 Національного університету охорони здоров'я України імені П.Л. Шупика, Київ, Україна.

Адреса для кореспонденції:

Шарікадзе Олена Вікторівна

04112, Київ, вул. Дорогожицька, 9

\section{Information about the author:}

Sharikadze Olena V. - Doctor of Medical Sciences, Associate Professor of the Department of Pediatrics № 1 of the Shupyk National Healthcare University of Ukraine, Kyiv, Ukraine.

Address for correspondence:

Olena Sharikadze

04112, Kyiv, Dorohozhytska str., 9 
ТЕСТОВІ ЗАПИТАННЯ

(один або декілька правильних варіантів відповідей на кожне запитання)

1. Який склад Афлубін ${ }^{\circledast}$ ІмуФаст?

$\square \quad 1$ льодяник містить 100 мг екстракту бузини, сік ехінацеї, екстракт імбиру, невелику кількість ментолу, вітамін С, вітаміни групи В, цинк, достатню кількість фолієвої кислоти, селен, вітамін D у дозі 10 мкг

$\checkmark 2$ льодяники містять 100 мг екстракту бузини, сік ехінацеї, екстракт імбиру, невелику кількість ментолу, вітамін С, вітаміни групи В, цинк, достатню кількість фолієвої кислоти, селен, вітамін D у дозі 10 мкг

2. 3 якого віку можна вживати Афлубін ${ }^{\circledR}$ ІмуФаст?

$\square$ тільки удорослих

$\square$ у дітей віком старше 2 років і дорослих

$\square$ у дітей віком старше 7 років і дорослих

$\square$ у дітей віком старше 12 років і дорослих

3. Чи можна застосовувати одразу 2 льодяники

Афлубін ${ }^{\circledast}$ ІмуФаст або розділити його на два прийоми?

$\square$ можна приймати 2 льодяники одразу

$\square$ можна розділити на 2 прийоми, але в останньому випадку цей поділ передбачає інтервал 6-12 год

$\square$ обидва варіанти правильні

4. Чи $\epsilon$ протипоказання до прийому Афлубін ${ }^{\circledR}$ ІмуФаст?

$\square$ індивідуальна непереносимість

$\square$ вік до 2 років

$\square$ вік до 7 років $\square$ період вагітності та годування грудьми

$\square$ немає протипоказань

5. Чи можна використовувати Афлубін ${ }^{\oplus}$ ІмуФаст для профілактики?

$\square$ можна і навіть потрібно це робити для того, щоб попередити розвиток ГРВІ

$\square$ не можна

6. Чи можна використовувати Афлубін ${ }^{\circledR}$ ІмуФаст у дітей або дорослих з цукровим діабетом?

$\square$ так, його склад $\epsilon$ абсолютно безпечним для пацієнтів із цукровим діабетом

$\square$ ні, Афлубін ${ }^{\oplus}$ ІмуФаст протипоказаний пацієнтам із цукровим діабетом

7. Яка рекомендована тривалість вживання Афлубін ${ }^{\circledast}$ ІмуФаст?

2-3 дні

$\square$ близько 8 діб, але можна вживати до 1 міс. і навіть довше, якщо немає ознак індивідуальної непереносимості

8. Через який час можна повторити курс прийому

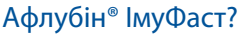

$\square$ за потребою: курс профілактики варто провести після контакту з хворим на респіраторну інфекцію, у випадку перевтоми, різкої зміни клімату тощо

$\square$ не частіше ніж 1 раз на рік

\section{Для отримання сертифіката дайте відповідь} на тестові запитання в режимі on-line на сайті журналу www.umj.com.ua або надішліть ксерокопію сторінок з відповідями разом з контактною інформацією за адресою: 01001, Київ-1, a/c «B»-82, ТОВ «МОРІОН»
ПІБ

Поштова адреса: індекс
область
район
місто
вулиця
будинок
квартира

Телефон
E-mail

